\title{
Quixotic Desire
}





\section{Quixotic Desire}

\section{Psychoanalytic}

Perspectives on

Cervantes

E D I T E D BY

Ruth Anthony El Saffar

A N D

Diana de Armas Wilson

Cornell University Press

ITHACA AND LONDON 


\section{LIBRARY}

\section{FEB 151994}

This book is published with the aid of a grant from the Program for Cultural Cooperation between Spain's Ministry of Culture and United States Universities.

\section{Copyright (C) 1993 by Cornell University}

All rights reserved. Except for brief quotations in a review, this book, or parts thereof, must not be reproduced in any form without permission in writing from the publisher. For information, address Cornell University Press, Sage House, 512 East State Street, Ithaca, New York 14850.

First published 1993 by Cornell University Press.

International Standard Book Number o-8014-2823-8 (cloth) International Standard Book Number o-8014-8081-7 (paper) Library of Congress Catalog Card Number 93-1336o

Printed in the United States of America

Librarians: Library of Congress cataloging information appears on the last page of this book.

@ The paper in this book meets the minimum requirements of the American National Standard for Information Sciences-Permanence of Paper for Printed Library Materials, ANSI Z39.48-1984. 